\title{
ANAESTHETIC MANAGEMENT FOR SUCCESSFUL SEPARATION OF TRIPUS ISCHIOPAGAL CONJOINED MALE TWINS
}

\author{
Chi-Ching Chao, Luciano Susetio, Kien-Wong Luu and Wing-Fai Kwan
}

Anstract

The anaesthetic management and postoperative care are described in a case of successful separation of tripus ischiopagal conjoined twins.

The separation of CONJOINED twins has always caused considerable interest, not only because of its rare incidence, but also because of the complexity of the operation itself, which presents a great challenge to both the surgical and anaesthetic teams. The incidence of conjoined twins, still-born or alive, is in the order of one in 50,000 to 60,000 , as reported by Aird' and Potter, ${ }^{2}$ respectively. Recent surveys by Milham on 22 sets quoted an incidence of $1: 166,000,{ }^{3}$ which was similar to Bender's incidence of 1:200,000.4 The ischiopagus variety is only six per cent of the whole unfortunate group and these are further subdivided into bipus, tripus and tetrapus according to the number of legs the patients have; and among these, tetrapus is the most common and these have been successfully separated most often. Tripus ischiopagus conjoined twins have three lower extremities between the two patients. Each baby shares a normal leg; the third leg is deformed and shared. Three separations of tripus ischiopagus have been reported. The first pair was done by Mester in 1971. ${ }^{5}$ Both twins survived surgery. Mayell reported another similar case in the same year but only one child survived. The third case was reported by Borde in $1974^{\circ}$ but unfortunately both children died after separation. On September 10, 1979, physicians at National Taiwan University Hospital in Taipei successfully separated male tripus ischiopagus twins. We now report the anaesthetic management for the separation of the conjoined twins (Figures I and 2).

\section{CASE REPORT}

The conjoined twins were delivered on December 23, 1976, at Kaohsiung. They had a nor-

Chi-Ching Chao, M.D.; Luciano Susetio, M.D.; Kien-Wong Luu, M.D., and Wing Fai Kwan, M.D.; Department of Anesthesiology, College of Medicine, National Taiwan University, Taipei, Republic of China.

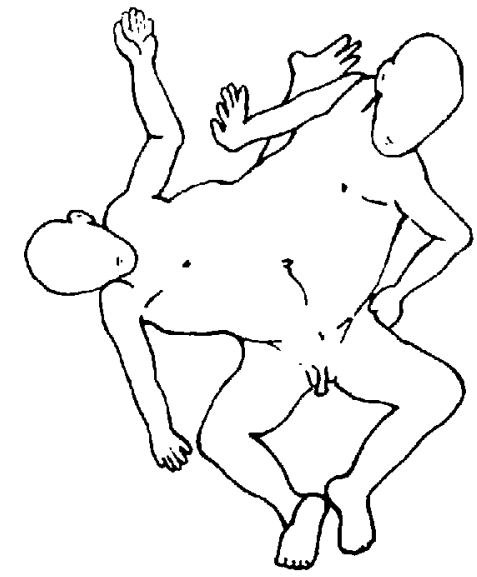

Figure 1 Ischiopagus conjoined twins. Relationship of the junction.

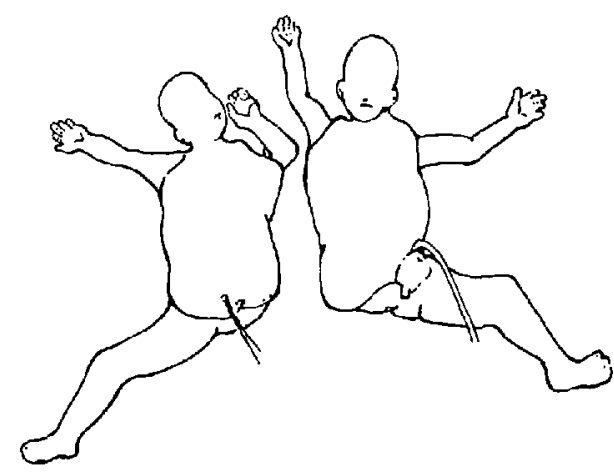

Figure 2 The twins separated.

mal spontaneous delivery at full term, and had no birth injury. After delivery they were transferred to Chung-Shun Medical College Hospital. Imperforate anus with rectal fistula was found at birth. Colostomy and a pull through operation was done. The recto-urethral fistula was ligated nine 65

Canad. Anaesth. Soc. J., vol. 27, no. 6, November 1980 
TABLE I

Preoperative Laboratory Data

\begin{tabular}{|c|c|c|}
\hline Preoperative examination & Baby A & Baby B \\
\hline Electrocardiogram & $\begin{array}{l}\text { Sinus tachycardia } \\
\mathrm{RAD} \\
\text { Incomplete RBBB } \\
\overline{\mathrm{C}} \mathrm{S}_{1} \mathrm{Q}_{3} \mathrm{~T}_{3} \text { pattern } \\
\text { Borderline } \mathrm{P} \text { wave } \\
\mathrm{R} / \mathrm{O} \mathrm{RVH}\end{array}$ & $\begin{array}{l}\text { Sinus tachycardia } \\
\text { RAD } \\
\text { Qr in I \& AVL } \\
\text { R/O Dextrocardia }\end{array}$ \\
\hline Chest X-ray & Negative & Negative \\
\hline $\begin{array}{l}\text { Liver function test } \\
\text { A/G }(3.8-5.1 / 2.2-3.1 \mathrm{gm} / \mathrm{dl}) \\
\text { Bilirubin D/T }(0-0.4 / 0.2-1.0 \mathrm{mg} / \mathrm{dl}) \\
\text { SGOT < } 40 \mathrm{~K} . \mathrm{U} . \\
\text { SGPT < } 35 \mathrm{~K} . \mathrm{U} . \\
\text { Alkaline phosphatase }(2.7-13.0 \mathrm{~K} . \mathrm{A} . \mathrm{U} .) \\
\text { ZTT (2-10 K.U.) }\end{array}$ & $\begin{array}{l}4.8 / 2.0 \\
0.19 / 0.6 \\
40 \\
37 \\
17.5 \\
8.6\end{array}$ & $\begin{array}{l}4.6 / 2.4 \\
0.1 / 0.3 \\
46 \\
41 \\
17.8 \\
9.0\end{array}$ \\
\hline $\begin{array}{l}\text { Haemogram } \\
\text { RBC }\left(\times 10^{4} / \mathrm{mm}^{3}\right) \\
\mathrm{Hgb}(\mathrm{gm} / 100 \mathrm{ml}) \\
\left.\text { WBC (per } \mathrm{mm}^{3}\right)\end{array}$ & $\begin{array}{c}390 \\
12.0 \\
5000\end{array}$ & $\begin{array}{c}380 \\
12.1 \\
7700\end{array}$ \\
\hline
\end{tabular}

Each twin had his own head, neck, chest, upper abdomen, upper extremities and one lower extremity. They shared the lower abdomen, buttocks, external genitalia and the third composite limb.

\section{Preoperative examination}

During the hospitalization at Chung-Shun Medical College hospital and NTUH, various examinations were done including intravenous pyelogram, cystography, upper and lower gastro-intestinal series, liver scan, angiography and routine examinations (Table I). The following data were obtained.

\section{Skeletal system}

Common pelvis, three lower extremities, one for each with the third leg, which had six digits, shared by both.

\section{Genito-urinary system}

Separate ureters and two separate bladders; one urethra, one penis and one scrotum. Cystoureteral reflux possibly existed.

\section{Gastro-intestinal system}

Separate upper GI and intestine; shared common short colon with a common anus.

\section{Angiography}

Two separate aortas, mesenteric arteries and renal arteries. The common colon received two separate blood supplies, one from each child. The common leg shared blood supply from both.

\section{Preoperative Preparations}

Several combined conferences were held before the operation, with the participation of doctors from the departments of paediatric surgery, general surgery, orthopedics, plastic surgery, urological surgery and anaesthesia, to discuss the general condition of the conjoined twins and the operative procedure.

Before the major operation for separation, there were two minor operations. The first operation was performed on July 27 to construct a cystostomy and to remove the composite limb. Propanidid $100 \mathrm{mg}$ intravenously was used for induction and succinylcholine chloride $20 \mathrm{mg}$ intravenously to facilitate tracheal intubation, one twin after the other, one anaesthetist taking care of each of the twins.

Inhalation anaesthetics were given through separate circle systems. Halothane 1.0 per cent in nitrous oxide 50 per cent with oxygen was used for maintenance of anaesthesia. Succinylcholine $10 \mathrm{mg}$ was given intermittently for necessary muscle relaxation. 
The second operation was performed on September 6 , four days before the separation. Central venous hyperalimentation was given. The twins were induced as for the first operation. No halothane was given because there would be only a four-day interval between this and the major operation.

Ketamine $10 \mathrm{mg}$ and succinylcholine $10 \mathrm{mg}$ intravenously were given intermittently for maintenance during this one and a half hour operation. The twins again recovered consciousness immediately after the operation. Mild cyanosis was noted in Chung-Jean (Baby A), but this disappeared after inhaling oxygen for half an hour. The postoperative course was otherwise good.

\section{Pneumoperitoneum}

In anticipation of the abdominoperineal wound closure following separation, pneumoperitoneum was established to stretch the parietes, hoping to make the approximation of the wound edges easier. Beginning on July 16, 1979 to August 30, 14 pneumoperitoneums were done. Volumes of $500101500 \mathrm{ml}$ of air were injected twice each week to produce a tense abdomen without respiratory embarrassment. The abdominal diameter, measured at its greatest circumference, was increased by $19.5 \mathrm{~cm}$. No anaesthetic was given during the procedure.

\section{Rehearsal}

Three rehearsals were held before the major operation to ensure efficient teamwork by each member of the surgical and the anaesthetic teams. This proved invaluable during the day of the operation.

\section{Specially designed equipment}

A specially designed pillow was made to overcome the difficulties in positioning on the operating table caused by the abnormal axis between the twins, so as to ensure a more comfortable position and easy immobilization.

\section{Anaesthesia}

The operation for the separation of the conjoined twins was done on September 10, 1979. The twins were $33 \frac{1}{2}$ months old and weighed $16.0 \mathrm{~kg}$.

There were two positionings during the whole operation; one before separation and the other afterwards. Each twin was premedicated with atropine $0.15 \mathrm{mg}$ and hydrocortisone $10 \mathrm{mg}$ intramuscularly one hour before operation. Induc- tion was carried out with thiopentone $80 \mathrm{mg}$ intravenously and succinylcholine $20 \mathrm{mg}$ was given intravenously to facilitate the tracheal intubation, which was done first on Baby $A$ and then on Baby B. An arterial line, a nasogastric tube and an electrocardiograph were set up after induction. As in the previous first minor operation, inhalation anaesthesia was given by a circle method of rebreathing and carbon dioxide absorption in a semi-closed system from an Ohio anaesthetic machine with a copper kettle vaporizer. Nitrous oxide 50 per cent with oxygen and intermittent halothane 0.5 per cent were used for maintenance. Ventilation was controlled manually at a rate of 30 breaths per minute throughout the operation. Succinylcholine 0.1 per cent was given by drip through the central venous catheter, with the rate adjusted as required.

The team consisted of four anaesthetists, one assigned to each twin with an anaesthetists assistant helping him. The other two anaesthetists were teaching staff of the department, giving direct supervision during the whole course of anaesthesia.

\section{The operation}

The operation was divided into four parts: the first part was the division of the liver and the gastro-intestinal system. The liver was divided by electrocauterization through a thick bridge which connected the two livers. The intestine was divided at its bifurcation. The proximal colon was given to Chung-Jean (Baby A) and the distal part to Chung-Yee (Baby B). The open wound of ileum of Chung-Jean (Baby A) was closed primarily and an ileocolostomy was done in Chung-Yee (Baby B).

The second part of the procedure involved the separation of the genito-urinary system. The anterior bladder with its urethra and external genitalia were given to Chung-Yee (Baby B). The ureter from the right kidney of Chung-Jean (Baby A) was divided at the vesico-ureteral junction and reimplanted in the posterior bladder. The right ureter of Chung-Yee (Baby B) was divided from the posterior ureter and implanted in the anterior bladder. The two bladders were then separated by the division of a connection which was present between the two bladder necks.

The third part of the operation included the division of the pelvis and the fused leg.

The fourth part of the operation was reconstruction and plastic surgery for the abdomen.

The whole operation took 13 hours and $30 \mathrm{~min}$ utes. The children regained consciousness imme- 
TABLE II

acid base balance During Anaesthesia

\begin{tabular}{|c|c|c|c|c|c|c|c|c|c|}
\hline \multirow[b]{2}{*}{ Time } & \multirow[b]{2}{*}{ Twin } & \multicolumn{2}{|c|}{$\mathrm{Pa}_{\mathrm{O}_{2}}$} & \multicolumn{2}{|c|}{$\mathrm{Pa}_{\mathrm{CO}_{2}}$} & \multirow{2}{*}{$\begin{array}{c}\mathrm{cH}^{+} \\
\mathrm{nmol} / \mathrm{l}(\mathrm{pH})\end{array}$} & \multirow{2}{*}{$\begin{array}{l}\mathrm{HCO}_{3}^{-} \\
\mathrm{mmol} / \mathrm{l}\end{array}$} & \multirow{2}{*}{$\begin{array}{l}\text { Base excess } \\
\mathrm{mmol} / 1\end{array}$} & \multirow{2}{*}{$\begin{array}{c}\mathrm{O}_{2} \text { Saturation } \\
\text { per cent }\end{array}$} \\
\hline & & $\mathrm{kPa}$ & Torr & $\mathrm{kPa}$ & Torr & & & & \\
\hline 0900 & $\begin{array}{l}\mathrm{A} \\
\mathrm{B}\end{array}$ & $\begin{array}{l}13.0 \\
16.6\end{array}$ & $\begin{array}{r}98 \\
125\end{array}$ & $\begin{array}{l}5.79 \\
4.06\end{array}$ & $\begin{array}{l}43.5 \\
30.5\end{array}$ & $\begin{array}{l}53.7(7.27) \\
38.02(7.42)\end{array}$ & $\begin{array}{l}18.6 \\
20.5\end{array}$ & $\begin{array}{l}-7.0 \\
-4.2\end{array}$ & $\begin{array}{l}95 \\
96\end{array}$ \\
\hline 1000 & $\begin{array}{l}\mathrm{A} \\
\mathrm{B}\end{array}$ & $\begin{array}{l}16.8 \\
19.0\end{array}$ & $\begin{array}{l}126 \\
143\end{array}$ & $\begin{array}{l}3.79 \\
4.46\end{array}$ & $\begin{array}{l}28.5 \\
33.5\end{array}$ & $\begin{array}{l}33.11(7.48) \\
35.48(7.45)\end{array}$ & $\begin{array}{l}24.2 \\
24.0\end{array}$ & $\begin{array}{l}+0.5 \\
+0.1\end{array}$ & $\begin{array}{l}96 \\
97\end{array}$ \\
\hline 1100 & $\begin{array}{l}\mathrm{A} \\
\mathrm{B}\end{array}$ & $\begin{array}{l}17.5 \\
21.3\end{array}$ & $\begin{array}{l}132 \\
160\end{array}$ & $\begin{array}{l}4.66 \\
4.46\end{array}$ & $\begin{array}{l}35.0 \\
33.5\end{array}$ & $\begin{array}{l}33.88(7.47) \\
36.31(7.44)\end{array}$ & $\begin{array}{l}25.6 \\
23.2\end{array}$ & $\begin{array}{l}+2.2 \\
-0.9\end{array}$ & $\begin{array}{l}96.5 \\
97\end{array}$ \\
\hline 1200 & A & 16.2 & 122 & 4.12 & 31.0 & $34.67(7.46)$ & 23.5 & -0.5 & 96 \\
\hline 1300 & $\begin{array}{l}A \\
B\end{array}$ & $\begin{array}{l}21.0 \\
19.9\end{array}$ & $\begin{array}{l}158 \\
150\end{array}$ & $\begin{array}{l}4.46 \\
3.13\end{array}$ & $\begin{array}{l}33.5 \\
23.5\end{array}$ & $\begin{array}{l}34.67(7.46) \\
33.88(7.47)\end{array}$ & $\begin{array}{l}24.8 \\
25.0\end{array}$ & $\begin{array}{l}+1.1 \\
+1.8\end{array}$ & $\begin{array}{l}97 \\
97\end{array}$ \\
\hline 1400 & $\begin{array}{l}\mathrm{A} \\
\mathrm{B}\end{array}$ & $\begin{array}{l}21.8 \\
18.3\end{array}$ & $\begin{array}{l}164 \\
138\end{array}$ & $\begin{array}{l}6.25 \\
4.12\end{array}$ & $\begin{array}{l}47.0 \\
31.0\end{array}$ & $\begin{array}{l}45.71(7.34) \\
31.62(7.5)\end{array}$ & $\begin{array}{l}23.3 \\
25.6\end{array}$ & $\begin{array}{l}-0.8 \\
+2.2\end{array}$ & $\begin{array}{l}97 \\
97\end{array}$ \\
\hline 1600 & $\begin{array}{l}\mathrm{A} \\
\mathrm{B}\end{array}$ & $\begin{array}{l}27.9 \\
14.6\end{array}$ & $\begin{array}{l}210 \\
110\end{array}$ & $\begin{array}{l}4.32 \\
4.85\end{array}$ & $\begin{array}{l}32.5 \\
36.5\end{array}$ & $\begin{array}{l}30.9(7.51) \\
33.11(7.48)\end{array}$ & $\begin{array}{l}26.6 \\
26.7\end{array}$ & $\begin{array}{l}+3.5 \\
+3.6\end{array}$ & $\begin{array}{l}97 \\
97\end{array}$ \\
\hline
\end{tabular}

A, Chung-Jean; B, Chung-Yee.

diately after the procedure. They were not extubated until their condition had become stable.

\section{Blood and fluid replacement}

During the operation there was considerable blood loss from the cut surface of the liver and during the separation of the pelvis and the bladder. Blood replacement was gauged by the amount of blood loss estimated by weighing of the gauze sponges, the amount from the suction bottle, and by the vital signs. The total blood transfusion for Chung-Jean (Baby A) was $5000 \mathrm{ml}$ and for Chung-Yee (Baby B) was $3250 \mathrm{ml}$. All coagulation factors were shown to be normal. Fluid was given at the rate of $4-5 \mathrm{ml} \cdot \mathrm{kg} / \mathrm{hr}$ to compensate for the insensible loss. Heart rate and blood pressure remained normal throughout the operation (Table IV) (Figure 4).

\section{Acid-base and electrolyte balance}

The arterial $\mathrm{pH}, \mathrm{Pa}_{\mathrm{O}_{2}}, \mathrm{~Pa}_{\mathrm{CO}_{2}}$, base excess and bicarbonate were checked every hour. Sodium bicarbonate was given only once, when base abnormality was noted. Table $I 1$ and Figure 3 show the course of acid-base balance during the whole course of the operation. Cortisone $25 \mathrm{mg}$ was given intravenously twice during the operation to prevent any adrenal insufficiency.

\section{Temperature}

The temperature of the twins was kept constant throughout the operation by warm or ice

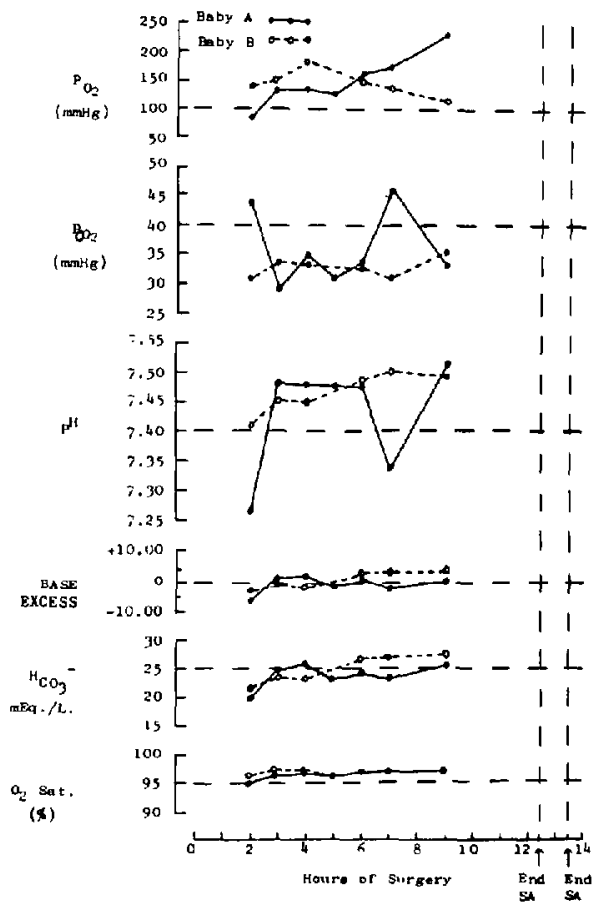

FIGURE 3 Acid-base balance during operation for separation.

water bags put beside them. No abnormal rise or fall in temperature was noted. 
TABLE III

(A) Postoperative Acid-Base Status (Chung-Jean)

\begin{tabular}{|c|c|c|c|c|c|c|c|c|c|}
\hline \multirow[b]{2}{*}{ Date } & \multirow[b]{2}{*}{ Time } & \multirow{2}{*}{$\begin{array}{c}\mathrm{cH}^{+} \\
\mathrm{nmol} / \mathrm{I}(\mathrm{pH})\end{array}$} & \multicolumn{2}{|c|}{$\mathrm{Pa}_{\mathrm{CO}_{2}}$} & \multicolumn{2}{|c|}{$\mathrm{Pa}_{\mathrm{O}_{2}}$} & \multirow{2}{*}{$\begin{array}{l}\mathrm{HCO}_{3}^{-} \\
\mathrm{mmol} / \mathrm{l}\end{array}$} & \multirow{2}{*}{$\begin{array}{l}\text { B.E. } \\
\mathrm{mmol} / \mathrm{l}\end{array}$} & \multirow[b]{2}{*}{ Rernarks } \\
\hline & & & $\mathrm{kPa}$ & Torr & $\mathrm{kPa}$ & Torr & & & \\
\hline Sept. 10 & 2145 & $30.20(7.52)$ & 4.52 & 34.3 & 18.13 & 136.3 & 27.7 & +5.0 & On VCR \\
\hline Sept. 11 & $\begin{array}{l}0045 \\
0820\end{array}$ & $\begin{array}{l}32.36(7.49) \\
28.18(7.55)\end{array}$ & $\begin{array}{l}4.85 \\
9.68\end{array}$ & $\begin{array}{l}36.5 \\
72.8\end{array}$ & $\begin{array}{l}19.62 \\
19.90\end{array}$ & $\begin{array}{l}147.5 \\
149.6\end{array}$ & $\begin{array}{l}28.0 \\
28.8\end{array}$ & $\begin{array}{l}+4.9 \\
+6.6\end{array}$ & $\begin{array}{l}\text { On VCR } \\
\text { Half hour } \\
\text { after.off } \\
\text { respirator } \\
\text { On VCR }\end{array}$ \\
\hline \multirow[t]{3}{*}{ Sept. 12} & $\begin{array}{l}0830 \\
1020\end{array}$ & $\begin{array}{l}24.55(7.61) \\
27.52(7.56)\end{array}$ & $\begin{array}{l}3.48 \\
3.99\end{array}$ & $\begin{array}{l}26.2 \\
30.0\end{array}$ & $\begin{array}{l}19.34 \\
20.36\end{array}$ & $\begin{array}{l}145.4 \\
153.1\end{array}$ & $\begin{array}{l}26.4 \\
26.8\end{array}$ & $\begin{array}{l}+6.6 \\
+5.9\end{array}$ & \multirow{3}{*}{$\begin{array}{l}\text { On VCR } \\
\text { Respirator } \\
\text { off } 0945 \\
\text { Extubation } \\
1630\end{array}$} \\
\hline & 1645 & $30.20(7.52)$ & 4.18 & 31.4 & 17.18 & 129.2 & 26.8 & +3.9 & \\
\hline & 2300 & $33.11(7.48)$ & 5.94 & 37.9 & 16.05 & 120.7 & 27.9 & +4.2 & \\
\hline \multicolumn{10}{|c|}{ (B) Postoperative Acid-Base Status (Chung-Yee) } \\
\hline Sept. 10 & 2325 & $28.84(7.54)$ & 3.21 & 24.1 & 19.13 & 143.8 & 20.9 & +0.1 & \\
\hline Sept. 11 & $\begin{array}{l}0045 \\
1030\end{array}$ & $\begin{array}{l}33.11(7.48) \\
31.62(7.50)\end{array}$ & $\begin{array}{l}4.08 \\
4.14\end{array}$ & $\begin{array}{l}30.7 \\
31.1\end{array}$ & $\begin{array}{l}16.81 \\
15.96\end{array}$ & $\begin{array}{l}126.4 \\
120.0\end{array}$ & $\begin{array}{l}23.0 \\
24.2\end{array}$ & $\begin{array}{l}+1.0 \\
+2.3\end{array}$ & $\begin{array}{l}\text { Extubation } \\
0950\end{array}$ \\
\hline
\end{tabular}

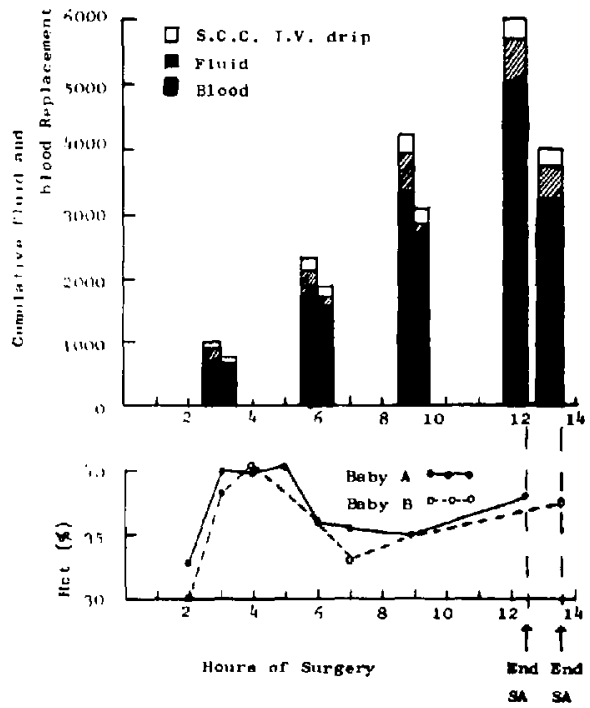

FIGURE 4 Blood replacement during operation.

\section{Recovery}

The two patients were able to move their legs while the surgeons were inserting the last two stitches. They regained consciousness immediately afterwards, with eyes opening, head moving, pink complexion and good respiratory effort and fine tidal volume.

\section{Postoperative Period}

The twins were given intensive supervision during the postoperative period (Table II A, B). The general condition of Chung-Yee (Baby B) was stable, except for a mild rise in the body temperature. Chung-Jean (Baby A) was cyanosed soon after the operation and controlled respiration was instituted. Cyanosis deepened during the first 24 hours postoperative. X-ray study showed that he had a serious diaphragmatic hernia. Volume control respiration was given and fortunately the symptons subsided. After weaning he was able to breath by his own efforts.

\section{Discussion}

The major problem of separation of conjoined twins, both of the operation itself and anaesthetic management, lies in its complexity rather than the difficulty. The successful separation of any conjoined twins mentioned in the literature can be attributed to detailed preoperative evaluation, thoughtful planning of the procedures based on the initial studies, accurate monitoring and correction of vital biological systems and adequate postoperative care. Timing for the operation is also important. Factors which contributed to the successful anaesthetic management in our case may be summarized as the following: 
TABLE IY

Blood Volume Management During Operation

\begin{tabular}{cccccc}
\hline \hline Time & Twin & $\begin{array}{c}\text { Succinylcholine 0.1\% } \\
\text { Intravenous drip (ml) }\end{array}$ & $\begin{array}{c}\text { Fluid } \\
\text { replacement (ml) }\end{array}$ & $\begin{array}{c}\text { Blood } \\
\text { replacement (m) }\end{array}$ & $\begin{array}{c}\text { Total } \\
(\mathrm{ml})\end{array}$ \\
\hline $0700-1000$ & A & 100 & 260 & 700 & 1060 \\
& B & 85 & 120 & 500 & 705 \\
$1000-1300$ & A & 100 & 50 & 1050 & 1200 \\
& B & 75 & 50 & 1000 & 1125 \\
$1300-1600$ & A & 100 & 200 & 1650 & 1950 \\
& B & 50 & 180 & 1000 & 1230 \\
$1600-1930$ & A & 85 & 100 & 1600 & 1785 \\
$1600-2040$ & B & 40 & 250 & 750 & 1040 \\
$0700-1930$ & A & 385 & 610 & 5000 & 5995 \\
$0700-2040$ & B & 250 & 600 & 3250 & 4100 \\
\hline
\end{tabular}

A, Chung-Jean; B, Chung-Yee.

\section{Timing}

Although from the standpoint of the anaesthetist we prefer the twins to be older, considering the complications due to UTI and the problems of psychological aspects the age of 2 years and $9 \frac{1}{2}$ months may be adequate. Detailed and informative preoperative evaluation, various useful preparations including pneumoperitoneum, hyperalimentation, removal of the bones of the common leg, suprapublic cystostomy, specially designed equipment and rehearsal all contributed to the smoothness of the operation and hence to shortening of the operative time. The experience from the two previous minor procedures was also useful.

Adequate monitoring and correction of vital biological systems

Because preoperative evaluation showed only peripheral abnormality of both circulations, we used separate vital signs as the guide for each individual in replacing blood loss and correction of acid-base status. The result was satisfactory, as more blood replacement was needed by Chung-Jean (Baby A). The use of different colours for recognition of different monitor lines and intravenous lines also proved helpful. Rational organization of anaesthetic teams and the advantage of consistency and mobility were valuable and, despite the 13-hour procedure, the anaesthetic personnel did not show excessive strain.

Appropriate choice of anaesthetic agents and anaesthetic techniques were the essence of the successful anaesthetic management. Halothane was used as the main inhalation agent because it had the advantage of easy control and its use could be adjusted according to conditions. It was not used during the previous minor procedures purposely to avoid the unlikely possibility of halothane liver toxicity. The successful use of succinylcholine intraveous drip in our case permitted small doses. Fresh blood which was rich in plasma cholinesterase was used for transfusion.

Adequate postoperative care cannot be too greatly emphasized.

\section{ACKNOWLEDGEMENT}

We wish to express our gratitude to Dr. Robert W. Virtue, Professor of Anesthesiology, University of Colorado Medical Center, Denver, U.S.A. for his reading of the manuscript.

\section{REFERENCES}

1. AIRD, I. Conjoined twins - further observations. Brit. Med. J., I: 1313-1315 (1959).

2. Potter, E.L. Chapt. 13, Pathology of the fetus and newborn. 2nd Ed. Chicago, Year book Med. Publ (1961).

3. Milham, S. JR. Symmetrical conjoined twins: an analysis of the birth records of twenty-two sets. $J$. Pediat. 69: 643-647 (1966).

4. BENDER, C. Studies on symmetrical conjoined twins. J. Pediat. 70: 1010-1011 (1967)

5. Mestel, A.L., Golinko, R.J., Wax, S.H. Steiger, B., Kelin, A., Filler, R. \& Landau, $S$. Ischiopagus tripus conjoined twins. Case report of a successful separation. Surg. $69: 75-83$ (1971).

6. Borde, J., Mitrofanoff, P., Wallon, P. ENSEL, J. \& DURAND, J.P. A case of asymmetrical ischiopagus symelius conjoined twins. Prog. in Ped. Surg. 7: 27-43 (1974). 


\section{RÉSUMÉ}

Les auteurs rapportent un cas de séparation chirurgicale avec survie d'enfants siamois. Les enfants de sexe mâle et âgés de 33 mois, étaient liés par le bassin et partageaient un mème colon et un même anus, ainsi que des organes génitaux externes communs; ils possédaient chacun un membre inférieur et en partageaient un deuxième (variété ischiopage à trois membres inférieurs). Ils ont été séparés lors d'une intervention complexe d'une durée de 13 heures; l'halothane et la succinylcholine ont été les agents anesthésiques principaux. Comme facteurs de succès dans ces cas, les auteurs font état de la nécessité d'une investigation préalable des grands systèmes (locomoteur, digestif, urinaire et vasculaire), de la nécessité de bien planifier tous les stades de l'intervention au cours de réunions de tous les spécialistes impliqués, de l'importance d'un monitoring adéquat avec maintien des paramètres biologiques vitaux (les deux jumeaux siamois ont été monitorisés et traités de façon individuelle). 